\title{
Interesi ili nešto drugo? Ekonomski stavovi i njihova utemeljenost u društvenoj strukturi u Hrvatskoj
}

\author{
DOI: $10.5613 /$ rzs.49.1.2 \\ UDK: $316.344 .2(497.5)$ \\ 316.644:33.012.4](497.5) \\ Izvorni znanstveni rad \\ Primljeno: 19. 2. 2019.
}

\author{
Andrija HENJAK \\ Fakultet političkih znanosti Sveučilišta u Zagrebu, Hrvatska \\ ahenjak@fpzg.hr \\ Bartul VUKSAN ĆUSA \\ Fakultet političkih znanosti Sveučilišta u Zagrebu, Hrvatska \\ bvuksan@fpzg.hr
}

\section{SAŽETAK}

Dosadašnje su studije pokazale da hrvatsku politiku ponajprije karakteriziraju politički rascjepi koji dijele birače na temelju odnosa prema povijesti i sociokulturnim vrijednostima, dok podjele među biračima temeljene na ekonomskim i distributivnim pitanjima gotovo posve izostaju. No, nepostojanje političkih podjela temeljenih na redistributivnim pitanjima ne znači da u javnosti ne postoji struktura stavova o ekonomskim pitanjima i da ti stavovi nisu utemeljeni u položaju pojedinaca u društvenoj strukturi. Koristeći se postizbornim anketnim istraživanjima na nacionalnoreprezentativnom slučajnom uzroku od po 1000 ispitanika provedenima uz parlamentarne izbore 2011., 2015. i 2016. godine, u radu se, upotrebom faktorske analize, nastoji utvrditi struktura stavova o ekonomskim pitanjima. U drugom koraku, koristeći se regresijskom analizom na podacima prikupljenim na nacionalnoreprezentativnom slučajnom uzroku od 1260 ispitanika u vrijeme parlamentarnih izbora 2015. godine, rad nastoji ispitati postoji li povezanost između stavova o ekonomskim pitanjima i socioekonomskog položaja. Analize su pokazale postojanje jasne i relativno stabilne strukture stavova o ekonomskim pitanjima u razdoblju obuhvaćenom istraživanjem, pri čemu je utvrđeno postojanje dviju dimenzija stavova, od kojih jedna mjeri ekonomski protekcionizam, a druga odnos prema ekonomskom liberalizmu. No, utvrđena je tek vrlo slaba povezanost između elemenata društvene strukture i stavova o distributivnim ekonomskim pitanjima.

Ključne riječi: socioekonomska struktura, ekonomski protekcionizam, ekonomski liberalizam, ekonomski stavovi, politički rascjepi 


\section{UVOD}

Od stjecanja neovisnosti zemlje, hrvatsku politiku karakterizira izražen nedostatak političkog natjecanja utemeljenog na pitanjima distribucije dohotka i ekonomskih interesa birača. Na gotovo svim izborima za tijela političke vlasti od 1990. godine nadalje nije zabilježen izraženiji pokušaj političke mobilizacije birača porukama koje se tiču njihovih ekonomskih interesa. Dosadašnja istraživanja javnog mnijenja i političkog ponašanja u Hrvatskoj utvrdila su da se politički rascjepi i političko ponašanje temelje prije svega na odnosu građana prema povijesti, ideološkim i vrijednosnim pitanjima, a vrlo malo na pitanjima distribucije ekonomske moći u društvu (Šiber, 2001, 1997; Henjak, Zakošek i Čular, 2013). Većina studija koje su analizirale utjecaj ekonomskih činitelja nije pronašla znatniji utjecaj socioekonomskog položaja birača niti stavova o distribuciji ekonomske moći u društvu na političko ponašanje. $S$ druge strane, studije koje su analizirale odnos dominantnih ideoloških rascjepa i stavova o ekonomskim pitanjima utvrdile su da ideološki rascjepi imaju izraženiju povezanost sa stavovima građana o pitanjima poput poreza na nekretnine nego njihov socioekonomski status (Henjak, 2007). No, činjenica da socioekonomski činitelji ne određuju biračko ponašanje ne znači da istodobno ne postoji oblikovana struktura stavova o ekonomskim i distributivnim pitanjima povezana sa socioekonomskim položajem ispitanika.

lako se dosad nije pokazalo politički osobito značajnim, možebitno postojanje stabilne strukture stavova o ekonomskim pitanjima utemeljene u socioekonomskom položaju pojedinca može imati značajan utjecaj na budući razvoj političkih rascjepa. Naime, postojanje oblikovanih stavova o pitanjima distribucije ekonomskih resursa, utemeljenih na istom ili sličnom socioekonomskom položaju većeg broja građana koji nisu politički mobilizirani na tim pitanjima, može otvoriti prostor novim strankama koje bi pokušale mobilizirati birače porukama koje postavljaju pitanje distribucije ekonomskih resursa u društvu. Stoga, u ovoj se studiji želi ispitati postoji li povezanost između socioekonomskog položaja pojedinca i njegovih stavova o pitanjima distribucije ekonomskih resursa koja bi mogla predstavljati osnovu za potencijalnu mobilizaciju birača na novoj dimenziji natjecanja, a time osnovu za promjenu strukture političkih rascjepa. To pitanje postaje osobito važno pojavom novih stranaka poput Živog zida i Mosta, nastalih izvan dosad prevladavajuće strukture političkih rascjepa mobilizirajući prije svega mlađe birače koji se u manjoj mjeri identificiraju s lijevim i desnim političkim identitetima u Hrvatskoj (Henjak, 2018).

Kako bismo odgovorili na to pitanje, u ovom se radu u prvom koraku koristimo anketnim istraživanjima provedenima nakon izbora 2011., 2015. i 2016. godine i s pomoću faktorske analize pokušavamo utvrditi postoji li jasna i stabilna struktura 
stavova o distributivnim pitanjima koja je nužna za formiranje dimenzije političkog natjecanja utemeljene na pitanjima distribucije ekonomskih resursa. $U$ drugom koraku, koristeći se anketnim podacima prikupljenima neposredno nakon izbora 2015. godine, koji sadržavaju varijable nužne za precizno mjerenje položaja ispitanika u socioekonomskoj strukturi, s pomoću regresijske analize pokušavamo utvrditi postoji li povezanost stavova o distributivnim pitanjima sa socioekonomskim položajem pojedinaca.

\section{POLITIČKI RASCJEPI I STAVOVI O EKONOMSKIM PITANJIMA U HRVATSKOJ}

Početak demokratske politike u Hrvatskoj karakterizirala je, prije svega, mobilizacija političkih rascjepa oblikovanih u razdoblju tijekom i nakon Drugoga svjetskog rata kroz niz traumatičnih povijesnih događaja obilježenih konfliktima i nasiljem, u kojima su se formirali politički identiteti ljevice i desnice (Henjak, Zakošek i Čular, 2013). Takav povijesni razvoj proizveo je politički rascjep koji dijeli političke identitete ljevice i desnice na odnosu prema povijesti, religiji i tradiciji i njihovoj ulozi u definiranju suvremenoga hrvatskog društva. Dosadašnje studije političkog ponašanja u Hrvatskoj jasno upućuju na postojanje lijevog i desnoga političkog identiteta temeljenog na odnosu prema povijesti, odnosno prema Drugom svjetskom ratu i razdoblju socijalizma, viđenjima položaja Hrvatske u Jugoslaviji, odnosu prema ulozi religije u društvu te odnosu prema posljedicama modernizacijskih procesa u 20. stoljeću (Čular i Zakošek, 2004; Jou, 2010). Zakošek $(1994,1998)$ ističe kako je temeljni rascjep koji oblikuje hrvatski stranački sustav definiran različitim viđenjima položaja Hrvatske u odnosu na šire političke zajednice, različitim vizijama unutarnjeg ustrojstva Hrvatske, kao i različitim viđenjima položaja manjina, poglavito srpske, u Hrvatskoj. Šiber (1997) pokazuje da "politička biografija", odnosno pripadnost članova obitelji jednoj od sukobljenih strana tijekom Drugoga svjetskog rata, oblikuje odnos prema povijesnim događajima, pokretima i osobama, kao i pripadnost političkim identitetima ljevice i desnice. Istodobno, Šiber (2001) ne nalazi povezanost socioekonomskog položaja i stranačkih preferencija, a posljedično ne nalazi ni postojanje jasne interesne strukturiranosti političkih preferencija.

U analizi strukture političkih rascjepa Zakošek (2001) i Čular i Zakošek (2004) nalaze dominaciju teritorijalno-kulturnih i ideološko-kulturnih rascjepa utemeljenih u povijesnim podjelama te znatno manju važnost socioekonomskog rascjepa. Čular (2000), osvrćući se na biračko ponašanje na prvim višestranačkim izborima u Hrvatskoj, ističe kako je odnos prema jugoslavenskoj federaciji bio važna determinanta biračke odluke, što je isto oblik "povijesne" odrednice. Druge su studije također utvrdile da su povijesni i kulturni znatno važniji od ekonomskih činitelja u 
definiranju ideološkog identiteta i stranačke identifikacije hrvatskih građana, bilo da je riječ o stavovima i ponašanju na individualnoj razini, ili o distribuciji stranačkih preferencija na agregatnoj razini između različitih povijesnih regija (Henjak, Zakošek i Čular, 2013; Henjak, 2011; Grdešić, 2013; Glaurdić i Vuković 2016; Ferić, 2008). Nadalje, ne samo da povijesni i ideološki činitelji dominiraju u definiranju političkih identiteta i odnosa prema strankama, nego je odnos prema strankama izrazito povezan s stavovima o pojedinim ekonomskim pitanjima poput primjene poreza na nekretnine, neovisno o drugim činiteljima, što upućuje na mogućnost da stranačka identifikacija zapravo definira odnos prema jednom u osnovi distributivnom pitanju (Henjak, 2007).

Nasuprot tomu, Dolenec (2012) tvrdi da je odsutnost socioekonomskog rascjepa malo vjerojatan ishod za tranzicijsko društvo poput Hrvatske te zaključuje kako odsutnost jasne manifestacije ekonomskog rascjepa najvjerojatnije znači da on jednostavno nije mobiliziran zato što političke stranke ne reprezentiraju dovoljno dobro interese različitih socioekonomskih skupina. Kao potvrdu svoje tvrdnje Dolenec (2012: 78) navodi razlike u ekonomskim stavovima povezane sa subjektivnom percepcijom pripadnosti društvenim klasama kao jedinoj varijabli koja u njezinoj analizi mjeri socioekonomski status pojedinca.

No, za pouzdanu bi analizu utjecaja socioekonomske pozicije na stavove o distributivnim pitanjima na individualnoj razini bilo potrebno precizno mjeriti socioekonomsku poziciju pojedinca s više varijabli koje mogu zahvatiti sve teorijski relevantne dimenzije socioekonomskog statusa. Mjerenje socioekonomske pozicije kroz više dimenzija pouzdanije zahvaća stvarni socioekonomski položaj pojedinca nego njegova subjektivna evaluacija koja može ovisiti o nizu drugih činitelja potencijalno nepovezanih sa stvarnim socioekonomskim položajem (Oesch, 2006, 2013). S obzirom na to da empirijske studije političkog ponašanja u Hrvatskoj dosad nisu upućivale na postojanje bilo kakvih socioekonomskih rascjepa, analiza koja teži ustanoviti postoji li jasna struktura stavova o distributivnim pitanjima utemeljena u društvenoj strukturi nužno bi se morao koristiti dovoljno preciznim instrumentom mjerenja socioekonomske pozicije koji bi zahvatio sve njezine teorijski značajne dimenzije.

Empirijsku analizu utemeljenosti stavova o distributivnim pitanjima u društvenoj strukturi jednim dijelom donose i nedavne studije koje istražuju postojanje i strukturu egalitarnog sindroma u Hrvatskoj (Štulhofer i Burić, 2015; Vuković, Štulhofer i Burić, 2017). Studije egalitarnog sindroma djelomice zahvaćaju i stavove o distribuciji ekonomskih resursa i njihovo utemeljenje u socioekonomskoj poziciji pojedinca, pri čemu empirijska analiza determinanti egalitarnog sindroma na anketnim podacima na individualnoj razini pokazuje da su slabije obrazovani, oni s nižim prihodima i oni koji žive u manjim mjestima skloniji podržavati egalitarne 
vrijednosti (Vuković, Štulhofer i Burić, 2017; Rimac, Burić i Štulhofer, 2017). No, treba napomenuti da koncept egalitarnog sindroma ne obuhvaća samo odnos prema distribuciji ekonomskih resursa, nego i pojedine društvene vrijednosti poput odnosa prema obrazovanju, radu i poduzetništvu, odnosno stavove i vrijednosti koje nadilaze distributivna pitanja.

Nedavni razvoj događaja, odnosno pojava novih stranaka na izborima 2015. i 2016. godine pokazuje da se događaju promjene unutar dominantnog političkog rascjepa koji je, barem do pojave novih stranaka, proizvodio bipolaran stranački sustav u kojem su se veze između birača i stranka temeljile na pripadnosti lijevom i desnom političkom identitetu koji proizlaze iz tradicionalnih rascjepa. Pojava novih stranaka, po svemu sudeći, događa se kao posljedica odvajanja dijela birača od tradicionalnih rascjepa, što otvara prostor za restrukturiranje političkih rascjepa i potencijalno jačanje važnosti socioekonomskog položaja pojedinca pri definiranju političkih stavova i ponašanja te posljedično pojavu nove dimenzije natjecanja temeljene na distributivnim pitanjima.

\section{DRUŠTVENA STRUKTURA I STAVOVI O DISTRIBUTIVNIM PITANJIMA}

Gotovo da nema studija koje analiziraju povezanost distributivnih preferencija građana i njihove pozicije u društvenoj strukturi u Hrvatskoj. No, brojne studije analiziraju utjecaj društvene strukture na političke preferencije u razvijenim industrijskim društvima. U većini se empirijskih studija kao značajni činitelji koji utječu na distributivne preferencije identificiraju zanimanje, sektor zaposlenosti, vrsta posla, odnosno usmjerenost na rutinski ili nerutinski rad s jedne strane te na rad $s$ objektima i tehničkim procesima nasuprot radu s ljudima i simbolima s druge, zatim vrsta i razina obrazovanja, izloženost socijalnom riziku, spol te tržišna mobilnost i prenosivost radnih vještina. Ovdje ćemo u glavnim crtama prikazati način na koji spomenuti činitelji utječu na preferencije o ekonomskim i distributivnim pitanjima.

Najveći broj studija ističe obrazovanje kao najznačajniji činitelj koji oblikuje stavove i vrijednosti (Weakliem 2002; Van de Werfhorst i De Graaf, 2004; Stubager, 2008). Pritom, više studija nalazi kako je više obrazovanje povezano s liberalnijim političkim svjetonazorom (Van de Werfhorst i De Graaf, 2004; Stubager, 2008). Istodobno, brojne su studije utvrdile povezanost između obrazovanja i odnosa prema tržištu, redistribuciji i državnoj intervenciji (Weakliem, 2002; Kitschelt i Rehm, 2014). Naime, oni koji imaju tržišno unosnije i prenosive vještine, koje im omogućuju višu razinu dohotka, što je češće kod visokoobrazovanih, skloniji su tržišnoj alokaciji resursa. S druge strane, oni čije obrazovanje ograničava njihovu mogućnost tržišnog utrživanja vještina i oni koji nemaju visoku tržišnu pokretljivost, po 
pravilu nižeobrazovani, skloniji su podržavati redistributivne ekonomske politike (Iversen i Soskice, 2001; Kitschelt i Rehm, 2014; Rehm, 2009; Cusack, Iversen i Rehm, 2006).

Sektor zaposlenja predstavlja drugi značajan izvor preferencija o distributivnim pitanjima. Zaposlenje u privatnom i javnom sektoru nužno podrazumijeva različitu razinu izloženosti tržištu i njegovim procesima, što proizvodi različite političke preferencije, naročito o ekonomskim i distributivnim pitanjima, između zaposlenika javnog i privatnog sektora (Knutsen, 2002). Pritom su zaposlenici javnog sektora skloniji podržavati redistributivne ekonomske politike jer sami više ovise o državnoj potrošnji. S druge strane, zaposlenici privatnog sektora izloženiji su tržišnoj konkurenciji te su u odnosu na zaposlene u javnom sektoru skloniji protržišnim ekonomskim politikama (Knutsen, 2002). Istodobno, sličnu strukturu stavova možemo primijetiti i kod zaposlenih u izloženom i zaštićenom sektoru ekonomije. Zaposleni u sektorima izloženima vanjskoj konkurenciji poput dominantno izvozno orijentiranih industrija ili poslovnih usluga, koji svoje troškove ne mogu prebaciti na potrošače, skloniji su tržišnim rješenjima, za razliku od zaposlenih u zaštićenim sektorima, poput javnih komunalnih poduzeća ili industrija zaštićenih protekcionističkim mjerama, koji svoje troškove mogu prebaciti na potrošače (Wren i Rehm, 2013). No, zaposleni u izloženim sektorima, ako nisu u stanju nositi se s konkurencijom na tržištu, mogu biti skloniji podržavati protekcionističke politike koje će štititi njihov ekonomski status, bez obzira rade li u javnom ili privatnom sektoru.

Empirijske studije redovito ističu i utjecaj zanimanja na distributivne preferencije kroz činitelje poput položaja u hijerarhiji zanimanja, visine primanja i autonomije djelovanja na poslu (Weeden i Grusky, 2005; Macy, 1988; Oesch, 2006, 2013). Visokoobrazovani profesionalci i menadžeri, zaposleni na vodećim položajima, kao i oni s visokom autonomijom rada i visokom razinom primanja, skloniji su podržavati tržišna načela u ekonomiji, osim ako je riječ o sociokulturnim profesionalcima koji su zaposleni u javnom sektoru te su nešto skloniji podržavati redistributivne politike. Samozaposleni obrtnici i mali poduzetnici skloniji su podržavati protržišne ekonomske politike s obzirom na njihovu izloženost tržištu i manju usmjerenost na javni sektor. Kvalificirani i nekvalificirani radnici skloniji su podržavati redistributivne politike, ali valja napomenuti kako među njima mogu postojati manje razlike s obzirom na sektor zaposlenja, pri čemu su redistributivne preferencije izraženije kod onih u javnom sektoru. Uz zanimanje je povezana i vrsta posla koju osoba radi, pri čemu osnovne razlike postoje između onih koji rade na poslovima gdje su glavni predmet rada tehnički i administrativni procesi ili objekti te onih koji rade s osobama i kulturnim simbolima (Weeden i Grusky, 2005; Macy, 1988). lako vrsta posla prije svega utječe na stavove prema sociokulturnim pitanjima, a manje na stavove 
prema ekonomskim pitanjima, općenito su oni koji rade s osobama i kulturnim simbolima skloniji podržavati redistributivne politike u odnosu na one koji rade na poslovima koji se bave tehničkim procesima i dokumentima (Kitschelt i Rehm, 2014).

Izloženost socijalnom riziku i marginalna pozicija na tržištu rada važan su izvor preferencija o distributivnim pitanjima (Kitschelt i Rehm, 2014; Marx, 2014; Schwander i Häuserman, 2013). Pojedinci koji rade na nestalnim ili povremenim poslovima, kao i oni koji rade na poslovima s niskom plaćom i općenito niskom razinom sigurnosti posla, radi svoje će izloženosti riziku od gubitka posla i riziku od siromaštva podržavati redistributivne politike. $S$ druge strane, oni koji rade na sigurnim i dobro plaćenim poslovima bit će osjetno manje skloni redistributivnim politikama jer su s jedne strane manje izloženi socijalnom riziku, dok s druge redistributivne politike za njih znače više porezno opterećenje (McCall i Kenworthy, 2007). Vještine koje pojedinci posjeduju u svijetu rada također oblikuju preferencije o distributivnim pitanjima (DiPrete, 2002; Iversen i Soskice, 2001; Kitschelt i Rehm, 2014; Rehm, 2009). Točnije, oni čije su vještine tržišno isplativije i lakše prenosive s posla na posao podržavat će tržišna rješenja u organizaciji ekonomije i tražiti manje državne intervencije, s obzirom na to da o tome umnogome ovisi i njihova mogućnost tržišnog iskorištavanja vještina i znanja koje posjeduju. S druge strane, oni čije su vještine manje utržive i teže prenosive s posla na posao podržavat će politike usmjerene na redistribuciju dohotka i ograničenje uloge tržišnih mehanizama u ekonomiji budući da gubitak posla i dohotka za njih predstavlja znatno veći problem jer svoje vještine ne mogu lako preusmjeriti na drugi posao, što ih čini ovisnijima o državnim socijalnim programima (Iversen i Soskice, 2001; Rehm, 2009). Spol je također determinanta koja oblikuje preferencije o distributivnim pitanjima, pri čemu su žene sklonije podržavati redistributivne politike budući da državni socijalni programi podržavaju ekonomsku neovisnost žena kroz olakšavanje njihova sudjelovanja na tržištu rada i pomoći pri usklađivanju obiteljskih i radnih obveza (Iversen i Rosenbluth, 2006). 


\section{METODOLOGIJA: PODACI I MJERNI INSTRUMENTI}

Kako ne postoje ranije studije koje analiziraju strukturu stavova građana o ekonomskim pitanjima, prvi je korak ovog rada, primjenom faktorske analize, ispitati strukturu stavova o ekonomskim pitanjima u Hrvatskoj, utvrditi što čini sadržaj pojedinih dimenzija te provjeriti je li ta struktura stabilna kroz vrijeme. Tim postupkom utvrđujemo i sadržaj zavisnih varijabli koje mjere distributivne preferencije građana koje koristimo u drugom koraku analize, kad s pomoću regresijske analize ispitujemo povezanost položaja građana u društvenoj strukturi i stavova o ekonomskim pitanjima.

Kao osnovnim izvorom podataka u radu koristimo se podacima prikupljenima u anketi o položaju žena na tržištu rada i usklađivanju obiteljskog i radnog života koju je proveo Fakultet političkih znanosti Sveučilišta u Zagrebu u studenom i prosincu 2015. godine u sklopu IPA projekta Žene na tržištu rada, na nacionalnoreprezentativnom slučajnom uzorku od 1260 punoljetnih ispitanika. Tom se anketom koristimo kao primarnim izvorom podataka u faktorskoj analizi stavova o ekonomskim pitanjima te osnovnim izvorom podataka u regresijskoj analizi, budući da ima širok raspon varijabli koje omogućuju detaljno mjerenje socioekonomskog položaja. Uz tu studiju koristimo se i trima postizbornim anketama koje je proveo Fakultet političkih znanosti Sveučilišta u Zagrebu nakon parlamentarnih izbora 2011., 2015. i 2016. godine, koje nam služe za provjeru stabilnosti strukture stavova kroz više vremenskih točaka i izvora podataka. Sve tri postizborne ankete provedene su na nacionalnoreprezentativnom slučajnom uzorku od 1000 punoljetnih ispitanika. ${ }^{1}$ Sve četiri ankete koriste se istim setom varijabli koje mjere stavove o ekonomskim pitanjima, što omogućuje njihovo konzistentno mjerenje kroz više vremenskih točaka.

Set od sedam varijabli koje mjere ekonomske stavove uključuje tvrdnje o pravu banaka da same određuju kreditnu stopu, o tome trebaju li građani s višim prihodima plaćati i više poreze, o zabrani prodaje domaćih banki i tvrtki strancima, o smanjivanju poreza kako bi se poduzetnicima pomoglo u poslovanju, o lakšem otpuštanju radnika kako bi tvrtke lakše poslovale, o privatizaciji državnih firmi radi podizanja njihove efikasnosti i o smanjenju proračunske potrošnje nauštrb socijalnih davanja i prava. Sve su varijable mjerene na ordinalnoj skali od pet stupnjeva od kojih najniži pokazuje potpuno neslaganje, a najviši potpuno slaganje s izne-

Prikupljanje podataka za sve četiri ankete provedeno je na uzorcima koji su kreirani tako da su u prvom koraku odabrani lokaliteti, dok su u drugom koraku unutar lokaliteta odabrani ispitanici. U svim četirima anketama podaci su prikupljeni anketiranjem licem u licem. Postizbornu anketu za izbore iz 2011. godine provela je agencija IPSOS, kao aktivnost u sklopu projekta Izbori, stanke i parlament u Hrvatskoj. Postizborne ankete za izbore iz 2015. i 2016. godine provela je agencija Hendal sredstvima projekata Sveučilišta u Zagrebu dodijeljenih Fakultetu političkih znanosti. 
senom tvrdnjom. Skupovi varijabli donekle se razlikuju između anketa, tako da se varijabla koja mjeri odnos prema smanjivanju poreza za poduzetnike ne nalazi u anketi iz 2011. godine, ali u toj anketi postoji pitanje koje mjeri odnos prema radničkom samoupravljanju. Zavisne varijable, kojima se koristimo u regresijskoj analizi povezanosti stavova o distributivnim pitanjima i socioekonomskog položaja pojedinca, kreirali smo na temelju rezultata faktorske analize, koristeći podatke iz ankete o tržištu rada iz 2015. godine.

Nezavisne varijable kojima se koristimo u regresijskoj analizi mjere zanimanje ispitanika, imovinsko stanje kućanstva u kojem ispitanik živi, socijalnu isključenost kućanstva, obrazovanje ispitanika, sektor zaposlenja ispitanika, razinu ekonomskog rizika s kojim se ispitanik suočava na tržištu rada, broj djece u kućanstvu, broj nezaposlenih u kućanstvu, broj umirovljenika u kućanstvu, dob, spol i religioznost ispitanika. S obzirom na to da je anketa koja se koristi u analizi dizajnirana za prikupljanje podataka o svim članovima kućanstva, dio nezavisnih varijabli zapravo mjeri socioekonomski položaj kućanstva kao osnovne ekonomske jedinice u kojoj ispitanik živi, što je preciznija mjera socioekonomskog položaja nego mjera statusa samog ispitanika.

Prva nezavisna varijabla mjeri zanimanje ispitanika i operacionalizirana je kroz klasnu shemu koju je predložio Daniel Oesch, a koja kao kriterij podjele zanimanja uključuje kombinaciju elemenata hijerarhijske pozicije pojedinca s vrstom posla koju pojedinac radi (Oesch, 2006). Oescheva klasna shema dijeli zanimanja u skupine s obzirom na njihovu poziciju u organizacijskoj hijerarhiji i autonomiji na radnom mjestu $s$ jedne strane te vrsti posla, odnosno radu $s$ ljudima i kulturnim simbolima ili s objektima i dokumentima s druge strane. U radu koristimo prilagođenu Oeschevu shemu koja uključuje četiri hijerarhijske razine te podjelu poslova na tehničke, administrativne i sociokulturne, pri čemu u posljednju skupinu ulaze svi poslovi u osobnim uslugama. Na najnižoj razini hijerarhije zanimanja svi zaposleni koji rade rutinske poslove svrstani su $u$ istu kategoriju budući da je na toj razini predmet posla najmanje važan u definiraju socioekonomskog položaja i preferencija (Oesch, 2006).

Druga nezavisna varijabla mjeri izloženost ispitanika percipiranom ili stvarnom riziku nezaposlenosti. Varijabla je kreirana kao aritmetička sredina standardiziranih vrijednosti varijabli koje mjere učestalost epizoda nezaposlenosti ispitanika u posljednjih 12 mjeseci, učestalost i trajanje pojedinih epizoda nezaposlenosti u proteklih pet godina te broj epizoda nezaposlenosti koje su trajale dulje od šest mjeseci. Te četiri varijable međusobno su visoko korelirane s Cronbachovim a koeficijentom od 0,84 . Više vrijednosti te varijable označavaju višu ukupnu razinu izloženosti riziku od nezaposlenosti. Treća nezavisna varijabla mjeri sektor zaposlenja ispitanika, 
odnosno zaposlenost u javnom ili u privatnom sektoru, pri čemu više vrijednosti te varijable označavaju zaposlenost u privatnom sektoru.

Četvrta nezavisna varijabla mjeri imovinsko stanje kućanstva. Varijabla je sastavljena od binarnih čestica koje mjere posjeduje li kućanstvo kuću ili stan u kojem obitava ili ne, posjeduje li ostale nekretnine u kojima trenutačno ne obitava ili ih može koristiti za ekonomsku aktivnost, mogu li si članovi kućanstva priuštiti godišnji odmor, imaju li članovi kućanstva adekvatan standard života s obzirom na osnovne životne potrebe te mogu li podmiriti izvanredni novčani trošak. Varijabla je kreirana zbrajanjem pozitivnih odgovora na ta pitanja, pri čemu viša vrijednost te varijable označava kućanstva boljega imovinskog stanja. KR-20 pokazatelj interne konzistentnosti iznosi 0,64.

Peta nezavisna varijabla mjeri rizik socijalne isključenosti i siromaštva članova kućanstva. Ta je varijabla kreirana zbrajanjem sedam binarnih čestica koje mjere jesu li u posljednjih 12 mjeseci članovi kućanstva podigli nenamjenski kredit radi pokrivanja redovnih troškova, jesu li se zadužili na drugi način zbog istog razloga, jesu li trošili ušteđevinu ili prodali pokretninu za pokrivanje osnovnih potreba, jesu li se koristili pučkom kuhinjom, jesu li primili pomoć od grada ili općine radi pokrivanja osnovnih troškova te jesu li kasnili s plaćanjem najamnine, računa ili rate kredita. Više vrijednosti te varijable označavaju višu razinu rizika od socijalne isključenosti i siromaštva. KR-20 pokazatelj interne konzistentnosti iznosi 0,67.

Šesta nezavisna varijabla mjeri izloženost pojedinca kreditnom zaduženju i kreirana je kao aritmetička sredina varijabli koje mjere udio dohotka pojedinaca koji odlazi na otplatu stambenih kredita, namjenskih potrošačkih kredita, nenamjenskih potrošačkih kredita, duga po kreditnim karticama i minusa na tekućem računu. Cronbachov a koeficijent te varijable iznosi 0,53 . Sedma nezavisna varijabla mjeri broj djece u kućanstvu i kreirana je zbrajanjem svih članova kućanstva koji se još školuju, studiraju ili su ovisni članovi predškolske dobi. Osma nezavisna varijabla mjeri broj neaktivnih osoba u kućanstvu i uključuje nezaposlene, nesposobne za rad i neaktivne zbog drugih razloga. Deveta nezavisna varijabla mjeri broj umirovljenika u kućanstvu. Deseta nezavisna varijabla mjeri obrazovanje ispitanika na ordinalnoj skali od sedam vrijednosti počevši od završenoga osnovnog obrazovanja do završenog magisterija i doktorata, pri čemu više vrijednosti označavaju višu razinu obrazovanja. Jedanaesta nezavisna varijabla mjeri spol ispitanika pri čemu viša vrijednost označavaju ženski spol. Dvanaesta nezavisna varijabla mjeri dob ispitanika u godinama. Posljednja nezavisna varijabla mjeri religioznost ispitanika na ordinalnoj skali od pet stupnjeva od kojih najniži uključuje ateiste, a najviši uvjerene vjernike. 


\section{STRUKTURA STAVOVA O DISTRIBUTIVNIM PITANJIMA - REZULTATI FAKTORSKE ANALIZE}

Rezultati faktorske analize provedene metodom glavnih komponenti s oblimin rotacijom osi na podacima iz ankete o tržištu rada iz 2015. godine prikazani u Tablici 1 pokazuju da sedam varijabli koje mjere ekonomske stavove ispitanika daju dva faktora koji imaju svojstvenu vrijednost višu od 1, od kojih prvi objašnjava $32 \%$, a drugi oko $25 \%$ varijance. Prvi faktor pritom uključuje varijable koje mjere odnos prema ograničenju prava banaka na samostalno određivanje kamatnih stopa, poreznom sustavu koji bi više opterećivao bogate od siromašnih, zaštiti domaćih tvrtki i banaka od stranih kupaca i smanjenju poreza poduzetnicima radi lakšeg poslovanja. S obzirom na to da ujedinjuje negativan odnos prema stranom kapitalu i korporacijama, prema državi koja nameće poreze poduzetnicima te prema bogatima koje trebaju plaćati više poreze od ostalih, ta bi se dimenzija mogla opisati i kao ekonomski protekcionizam. Pritom je riječ o ekonomskom protekcionizmu u širem smislu, budući da se u empirijskim studijama ekonomski protekcionizam operacionalizira prije svega kao trgovinski protekcionizam (Mayda i Rodrik, 2005), dok ova dimenzija obuhvaća preferencije za zaštitu slabijih ekonomskih aktera od tržišne ili političke moći jačih ekonomskih aktera, odnosno preferenciju za redistribuciju ekonomske moći. Sadržaj te dimenzije ima dosta sličnosti s populističkim ekonomskim zahtjevima usmjerenim na ograničenje moći domaćeg i stranog kapitala u odnosu na obične građane (Eichengreen, 2018; Inglehart i Norris, 2016). Podrška smanjenju poreza poduzetnicima može se povezati s vrlo raširenom percepcijom u javnosti o neproduktivnoj državi koja predstavlja teret poduzetnicima koji se bore na tržištu i koja proizvodi uhljebe političkom intervencijom trošeći novac poreznih obveznika, pri čemu su poduzetnici u poziciji žrtve u odnosu na predatorsku državu. Podrška ograničenju prava banaka da same određuju kamatnu stopu te podrška zabrani prodaje domaćih tvrtki strancima može se promatrati i kao zahtjev za ograničenjem moći korporacija prema građanima, ali i kao zahtjev za ograničenjem uloge stranog kapitala u hrvatskoj ekonomiji. Podrška progresivnom porezu može se promatrati i kao podrška redistribuciji ekonomske moći, pri čemu bogate treba natjerati da doprinesu društvu sukladno svojoj ekonomskoj snazi.

Drugi faktor čine varijable koje mjere odnos prema lakšem otpuštanju radnika radi lakšeg poslovanja tvrtki, potrebi privatizacije državnih tvrtki radi nemogućnosti države da efikasno njima upravlja i odnos prema potrebi smanjivanja proračunske potrošnje nauštrb socijalnih davanja i prava. Taj faktor pokazuje postojanje dimenzije koja obuhvaća pozitivne stavove o ekonomskom liberalizmu, odnosno uključuje preferencije za tržišna i liberalna načela organizacije ekonomije nasuprot redistribuciji i državnoj intervenciji. 
Tablica 1. Struktura stavova o ekonomskim pitanjima u anketi iz 2015. godine: rezultati faktorske analize s oblimin rotacijom osi

\begin{tabular}{lcc}
\hline čestice & $\mathbf{1}$ & $\mathbf{2}$ \\
\hline $\begin{array}{l}\text { Država treba ograničiti pravo banaka da same određuju kamatnu } \\
\text { stopu za kredite građanima. }\end{array}$ & $\mathbf{0 , 7 5}$ & $-0,02$ \\
\hline $\begin{array}{l}\text { Porezni sustav bi trebao biti organiziran tako da oni koji imaju veće } \\
\text { prihode plaćaju više poreze. }\end{array}$ & $\mathbf{0 , 6 6}$ & 0,17 \\
\hline $\begin{array}{l}\text { Banke i tvrtke potrebno je sačuvati u domaćem vlasništvu jer prodaja } \\
\text { strancima šteti domaćoj ekonomiji. }\end{array}$ & $\mathbf{0 , 7 8}$ & $-0,01$ \\
\hline $\begin{array}{l}\text { Država treba smanjiti poreze kako bi pomogla poduzetnicima da } \\
\text { bolje posluju. }\end{array}$ & $\mathbf{0 , 7 3}$ & 0,12 \\
\hline $\begin{array}{l}\text { Potrebno je tvrtkama omogućiti lakše otpuštanje zaposlenika kako bi } \\
\text { lakše poslovale. }\end{array}$ & $-0,12$ & $\mathbf{0 , 8 1}$ \\
\hline $\begin{array}{l}\text { Tvrtke u državnom vlasništvu treba privatizirati jer država ne može } \\
\text { njima efikasno upravljati. }\end{array}$ & 0,19 & $\mathbf{0 , 7 2}$ \\
\hline $\begin{array}{l}\text { Potrebno je smanjiti proračunsku potrošnju, čak i ako to znači sman- } \\
\text { jivanje plaća, mirovina i socijalnih prava. }\end{array}$ & 0,13 & $\mathbf{0 , 7 9}$ \\
\hline $\begin{array}{l}\text { ukupna objašnjena varijanca (\%) } \\
\text { svojstvena vrijednost }\end{array}$ & 32,01 & 25,23 \\
\hline korelacija između faktora & 2,24 & 1,76 \\
\hline Cronbachov a koeficijent čestica koje tvore faktor & 0,09 & 0,69 \\
\hline
\end{tabular}

Distribucija varijabli uključenih u faktorsku analizu, prikazana na Slici 1 , pokazuje prilično asimetričnu distribuciju za četiri varijable koje mjere stavove označene kao ekonomski protekcionizam. Gotovo sedamdeset posto ispitanika u anketi slaže se ili se izrazito slaže s ograničenjima prava banaka, ograničenjima uloge stranaca u ekonomiji, progresivnim porezima za bogate te smanjenjem poreznog opterećenja za poduzetnike. Distribucije vrijednosti tih četiriju varijabli gotovo su identične, što potvrđuje nalaz faktorske analize o postojanju jasne dimenzije ekonomskog protekcionizma, ali i o njegovoj raširenosti. S druge strane, distribucije varijabli koje mjere odnos prema ekonomskom liberalizmu pokazuje ravnomjernije raspršenje vrijednosti na cijeloj ljestvici, s nešto manjim postotkom ispitanika koji se u potpunosti slažu s tržišnim načelima organizacije ekonomije. Niska korelacija između dvaju faktora pokazuje da su te dvije dimenzije ekonomskih stavova mjerene sa sedam uključenih varijabli međusobno neovisne. 
Slika 1. Distribucija stavova na sedam varijabli koje mjere ekonomske stavove u anketi iz 2015. godine

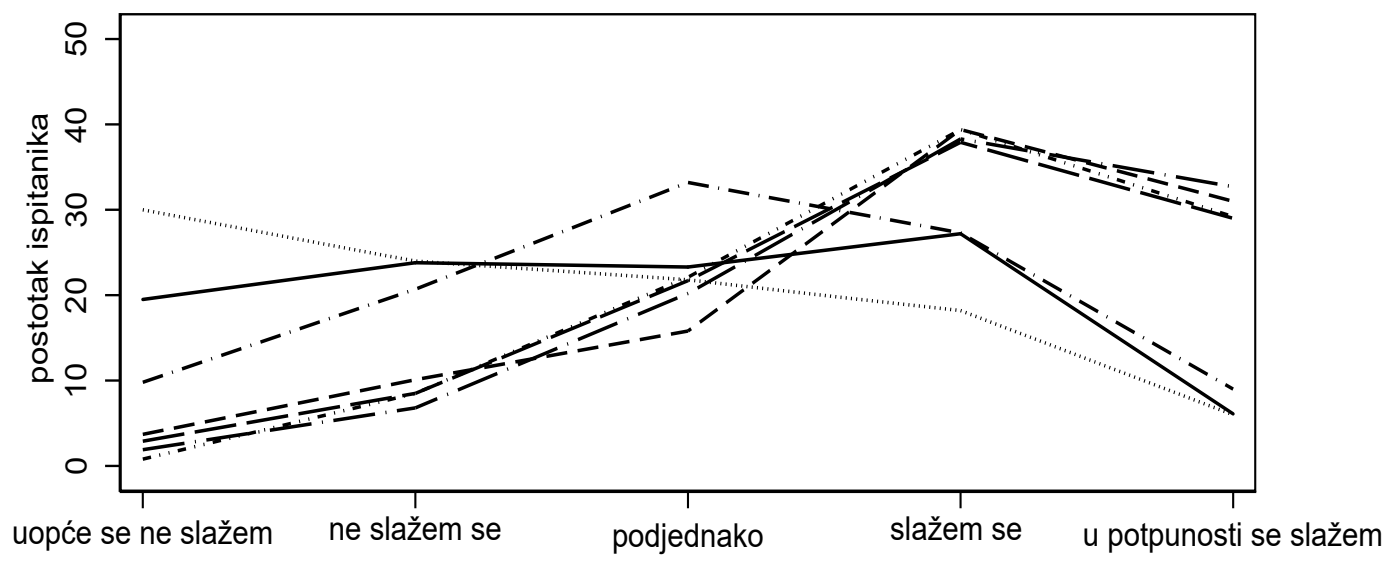

$$
\begin{aligned}
& \text { — smanjivane poreza i troškova - - - o ograničenje prava banaka } \\
& \text { lakše otpuštanje radnika - - - progresivni porezi } \\
& \text { - - - privatizacija javnih tvrtki _ ........ ograničenje ulaska stranaca } \\
& \text { - - manji porezi poduzetnicima }
\end{aligned}
$$

Kako bismo provjerili konzistentnost i stabilnost tih dviju dimenzija stavova o ekonomskim pitanjima, proveli smo dodatne faktorske analize na podacima postizbornih anketa provedenih nakon izbora 2011., 2015. i 2016. godine. Rezultati tih analiza prikazanih u Tablici 2 pokazuju postojanje dviju dimenzija ekonomskih stavova identičnog sadržaja onima prikazanim u Tablici 1 u anketama iz 2015. i 2016. godine, pri čemu jedan faktor pokazuje odnos prema ekonomskom protekcionizmu, dok drugi pokazuje odnos prema ekonomskom liberalizmu. Međutim, u anketi iz 2011. godine možemo primijetiti osjetno višu korelaciju između faktora, znatno veću razliku u objašnjenoj varijanci i svojstvene vrijednosti drugog faktora u odnosu na prvi te nekoliko varijabli koje imaju znatna faktorska opterećenja za oba izlučena faktora. Ti rezultati upućuju na postojanje jedinstvenog faktora koji mjeri lijeve odnosno desne ekonomske stavove 2011. godine. Razlika u rezultatima između 2011. te 2015. i 2016. godine može biti posljedica razlika u strukturi varijabli između anketa, ali može biti i posljedica promjena u strukturi stavova koje su se dogodile između 2011. i 2015. godine. Anketa iz 2011. godine uključuje varijablu koja mjeri stavove o radničkom samoupravljanju i ograničenju ulaska stranaca na domaće tržište, ali nema varijablu koja mjeri odnos prema smanjivanju poreza za 
poduzetnike. S obzirom na raspoložive podatke, ne možemo provjeriti što je uzrok veće korelacije između dimenzija u anketi iz 2011. godine i to pitanje će tražiti istraživanje sa širim opsegom podataka, što u ovom radu ne možemo napraviti. Izuzevši taj moment, struktura faktora gotovo je identična kroz tri ankete provedene 2015. i 2016. godine i tri različita uzorka, što upućuje na to da barem u tom ograničenom vremenskom kontekstu struktura stavova mjerenih tim varijablama nije rezultat slučajnosti. $S$ obzirom na to da ranije ankete nemaju ista pitanja koja mjere ekonomske stavove, ne možemo provjeriti kakva je struktura stavova postojala prije 2011. godine.

Tablica 2. Struktura stavova o ekonomskim pitanjima u anketama iz 2011., 2015. i 2016. godine: rezultati faktorske analize s oblimin rotacijom osi

\begin{tabular}{lcc|cc|cc}
\hline izbori & \multicolumn{2}{c}{ 2011. } & \multicolumn{2}{c|}{$\mathbf{2 0 1 5}}$. & \multicolumn{2}{c}{$\mathbf{2 0 1 6 .}$} \\
\hline faktor & $\mathbf{1}$ & $\mathbf{2}$ & $\mathbf{1}$ & $\mathbf{2}$ & $\mathbf{1}$ & $\mathbf{2}$ \\
\hline smanjivanje proračunske potrošnje & 0,21 & $\mathbf{0 , 7 2}$ & $\mathbf{0 , 7 4}$ & -0.12 & $\mathbf{0 . 8 0}$ & 0.05 \\
\hline lakše otpuštanje zaposlenika & 0,23 & $\mathbf{0 , 7 7}$ & $\mathbf{0 , 7 9}$ & -0.10 & $\mathbf{0 . 7 5}$ & -0.20 \\
\hline privatizacija tvrtki & 0,47 & $\mathbf{0 , 6 2}$ & $\mathbf{0 , 7 4}$ & 0.13 & $\mathbf{0 . 7 6}$ & 0.05 \\
\hline $\begin{array}{l}\text { osiguranje naknada za } \\
\text { nezaposlene }\end{array}$ & $\mathbf{0 , 6 6}$ & 0,18 & 0,04 & $\mathbf{0 . 6 3}$ & -0.14 & $\mathbf{0 . 5 9}$ \\
\hline ograničenje autonomije banaka & $\mathbf{0 , 6 2}$ & 0,47 & $-0,02$ & $\mathbf{0 . 6 8}$ & -0.07 & $\mathbf{0 . 6 5}$ \\
\hline veći porezi za bogate & $\mathbf{0 , 6 3}$ & 0,32 & $-0,10$ & $\mathbf{0 . 6 3}$ & -0.01 & $\mathbf{0 . 7 0}$ \\
\hline smanjivanje poreza za poduzetnike & - & - & 0,21 & $\mathbf{0 . 5 3}$ & -0.02 & $\mathbf{0 . 5 6}$ \\
\hline ograničenje ulaska stranaca & $\mathbf{0 , 7 8}$ & 0,13 & 0,33 & 0.19 & 0.06 & 0.28 \\
\hline radničko samoupravljanje & $\mathbf{0 , 6 7}$ & 0,27 & - & - & - & - \\
\hline svojstvena vrijednost & 2,86 & 1,10 & 1,89 & 1.61 & 1.89 & 1.60 \\
\hline ukupno objašnjena varijanca (\%) & 35,73 & 13,73 & 23,61 & 20.09 & 23.66 & 19.99 \\
\hline korelacija između faktora & \multicolumn{2}{|c|}{0,35} & & 0,06 & & $-0,03$ \\
\hline
\end{tabular}

Taj nalaz pokazuje da rezultati iz Tablice 1 nisu samo jednokratna pojava karakteristična za kontekst izbora iz 2015. godine ni korišten uzorak. Ipak, potrebno je navesti da slika o dvjema dimenzijama stavova koja proizlazi iz te analize umnogome ovisi i o sadržaju varijabli korištenih za mjerenje stavova prema pojedinim ekonomskim pitanjima. Drukčija struktura varijabli, koja uključuje druge čestice, mogla 
bi dati drukčiju sliku strukture ekonomskih stavova, a moguće je i da varijable korištene $u$ analizi ne mjere sve dimenzije stavova koje objektivno postoje u javnosti. Stoga nije moguće tvrditi da ta analiza predstavlja potpunu sliku ekonomskih stavova, niti da ta slika vrijedi izvan vremenskog okvira obuhvaćenog podacima. Ali s obzirom na raspoložive podatke, ne možemo sa sigurnošću reći je li razlika strukture iz 2011. u odnosu na ostale godine posljedica promjena u strukturi stavova, pri čemu se jedna dimenzija postupno razdvaja na dvije nakon 2011. godine. Ipak, relativno jasan sadržaj i stabilnost dimenzija stavova koju daje faktorska analiza u više anketa provedenih na različitim uzorcima, kao i činjenica da se čestice koje mjere stavove o različitim pitanjima opetovano slažu na gotovo istovjetne faktore, upućuje na to da analiza relativno pouzdano zahvaća dio relevantnih stavova o ekonomskim pitanjima, barem u kontekstu izbora 2015. i 2016. godine.

\section{POLOŽAJ U DRUŠTVENOJ STRUKTURI I STAVOVI O EKONOMSKIM PITANJIMA - REZULTATI REGRESIJSKE ANALIZE}

$\mathrm{Na}$ temelju rezultata faktorske analize kreirali smo dvije zavisne varijable koje koristimo u regresijskoj analizi. Prva zavisna varijabla mjeri odnos prema ekonomskom liberalizmu, odnosno preferencijama za tržišna načela organizacije ekonomije, dok druga zavisna varijabla mjeri preferencije za protekcionističke politike. Prva zavisna varijabla, sukladno rezultatima faktorske analize, sastoji se od triju čestica koje mjere odnos ispitanika prema smanjenju proračunske potrošnje ako to uključuje i smanjenje plaća i mirovina, prema otpuštanju zaposlenika ako bi to omogućilo tvrtkama da lakše posluju te prema privatizaciju državnih tvrtki radi efikasnijeg poslovanja. Varijabla je kreirana uzimanjem aritmetičke sredine tih triju čestica, pri čemu više vrijednosti označavaju višu razinu podrške ekonomskom liberalizmu. Cronbachov a koeficijent indeksa iznosi 0,67.

Druga zavisna, sukladno rezultatima faktorske analize, sastoji se od četiriju čestica koje mjere stav ispitanika prema ograničavanju prava banaka da same određuju kamatnu stopu, prema poreznom sustavu u kojem oni s višim prihodima plaćaju veće poreze, prema stranom vlasništvu nad bankama i tvrtkama te prema smanjenju poreza kako bi se omogućilo lakše poslovanje poduzetnicima. Varijabla je kreirana uzimanjem aritmetičke sredine tih četiriju čestica, pri čemu više vrijednosti označavaju višu razinu ekonomskog protekcionizma. Cronbachov a koeficijent indeksa iznosi 0,71.

Rezultati dviju OLS regresijskih analiza prikazani su na slikama 2 i 3. Zajedničko tim analizama jest da je eksplanatorna snaga modela niska i pokazuje da 
varijable koje mjere položaj ispitanika u društvenoj strukturi imaju vrlo malu ulogu u objašnjavanju varijacije u stavovima o ekonomskim pitanjima. Koeficijenti determinacije tek su nešto viši od 0,05 , što je, komparativno uzevši, vrlo nisko.

Niska razina objašnjene varijance kod varijable koja mjeri odnos prema ekonomskom protekcionizmu može biti posljedica prilično asimetrične distribucije stavova na svim varijablama od kojih je kreirana, što samo po sebi donekle smanjuje varijancu te zavisne varijable. To nije slučaj kod varijable koja mjeri odnos prema ekonomskom liberalizmu jer čestice koje je tvore imaju znatno ravnomjerniju distribuciju. No, treba istaknuti da je distribucija standardiziranih reziduala u objema OLS regresijama gotovo identična normalnoj distribuciji, što pokazuje da distribucija varijabli od kojih su kreirane zavisne varijable sama po sebi ne proizvodi pristrane rezultate niti nosi problem heteroskedastičnosti u regresijskoj analizi.

$U$ regresijskoj analizi determinanti odnosa prema ekonomskom liberalizmu statistički značajnima su se pokazale varijable koje mjere broj nezaposlenih u kućanstvu, broj umirovljenika u kućanstvu, socijalnu isključenost kućanstva, izloženost kućanstva kreditu i religioznost ispitanika (Slika 2). Sve te varijable povezane su s negativnim odnosom prema tržištu kao načelu organizacije ekonomije, gdje veći broj nezaposlenih i umirovljenika u kućanstvu, kao i veća izloženost kućanstva kreditu i viši stupanj socijalne isključenosti, smanjuju podršku ekonomskom liberalizmu. Isto je slučaj i s religioznijim ispitanicima, što se može objasniti mogućom nevoljkošću religioznih pojedinaca sklonih komunitarnom shvaćanju društva da prihvate tržište kao osnovni model organizacije društva i odnosa u njemu. Međutim, supstancijalni efekti svih tih varijabli, ako in gledamo pojedinačno, poprilično su niski, a utjecaj na promjenu odnosa prema tržištu zapravo marginalan. Tek kombinirani efekti više varijabli zajedno mogu proizvesti osjetnije efekte na odnos prema tržištu, odnosno, tek kombinacija visoke razine socijalne isključenosti i izloženosti kreditu, zajedno s velikim brojem ovisnih članova, proizvodi znatnije smanjenje podrške ekonomskom liberalizmu. 
Slika 2. Rezultati OLS regresijske analize s odnosom prema ekonomskom liberalizmu kao zavisnom varijablom

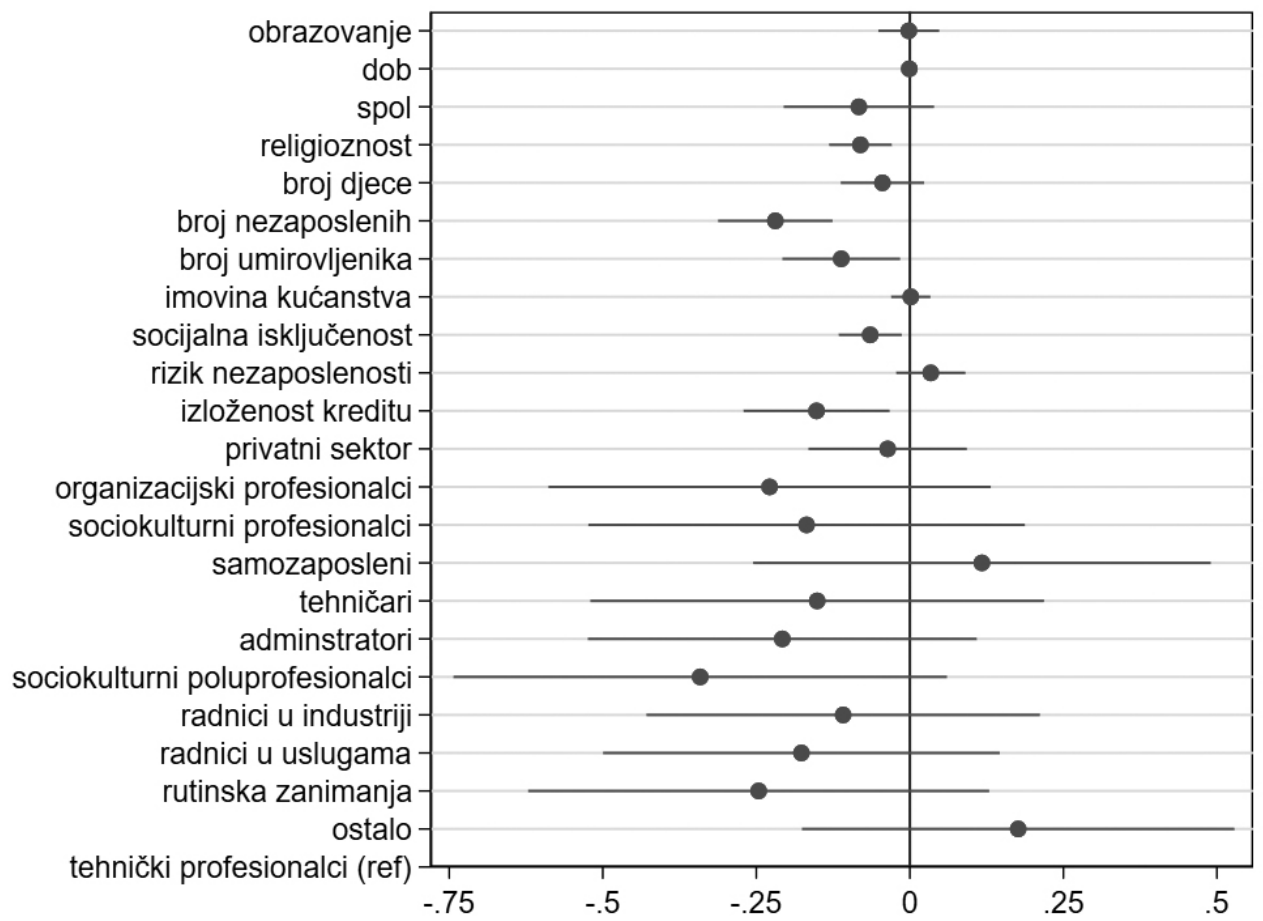

Konstanta $=3,77(0,29), N=1112, R^{2}=0,07, F=3,99, p(F)<0,001$.

Napomena: točke na slici označavaju vrijednosti nestandardiziranih regresijskih koeficijenata, a vodoravne linije na kojima se nalaze označavaju 95-postotni interval pouzdanosti. Statistički su značajni oni koeficijenti čiji intervali pouzdanosti ne sijeku okomitu liniju koja ima ishodište u vrijednosti 0 .

Regresijska analiza vezana uz odnos prema ekonomskom protekcionizmu kao zavisnoj varijabli pokazuje pet statistički značajnih nezavisnih varijabli (Slika 3). Te varijable mjere socijalnu isključenosti kućanstva, razinu izloženosti kreditu, zaposlenost ispitanika u privatnom sektoru te broj djece i umirovljenika u kućanstvu. Viša razina izloženosti kreditu povezana s višom razinom sklonosti ekonomskom protekcionizmu, a slične efekte ima i broj radno neaktivnih članova u obitelji, odnosno život u kućanstvima koja imaju veći broj djece ili umirovljenika. Zaposleni u privatnom sektoru pokazuju višu razinu sklonosti ekonomskom protekcionizmu u odnosu na zaposlene u javnom sektoru. S druge strane, pomalo neočekivano, socijalno isključeni manje su skloni protekcionističkim mjerama, što može biti izraz 
njihova nepovjerenja u mogućnost poboljšanja vlastitog položaja uz pomoć državne intervencije, odnosno vjerovanja da je državna socijalna intervencija vođena prije svega ciljem mobilizacije političke podrške, a ne pomoći socijalno isključenima. No, kao i u prethodnoj regresijskoj analizi, eksplanatorna snaga modela je mala, a tek kombinirani efekti ekstremnih vrijednosti više nezavisnih varijabli dovode do osjetnije promjene u razini ekonomskog protekcionizma.

\section{Slika 3. Rezultati OLS regresijske analize s odnosom prema ekonomskom} protekcionizmu kao zavisnom varijablom

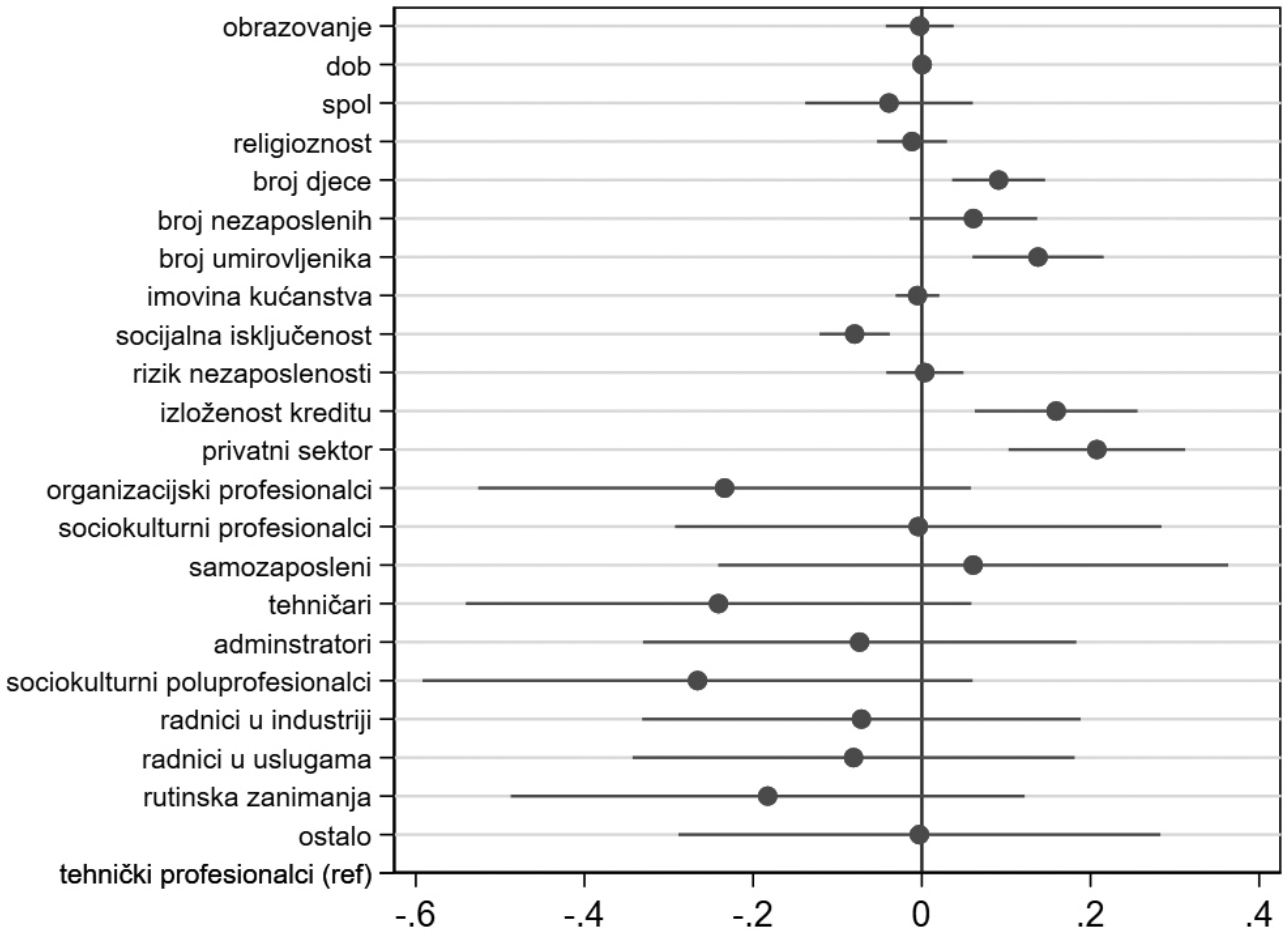

Konstanta $=3,61(0,23), N=1112, R^{2}=0,06, F=2,94, p(F)<0,001$.

Napomena: točke na slici označavaju vrijednosti nestandardiziranih regresijskih koeficijenata, a vodoravne linije na kojima se nalaze označavaju 95-postotni interval pouzdanosti. Statistički su značajni oni koeficijenti čiji intervali pouzdanosti ne sijeku okomitu liniju koja ima ishodište u vrijednosti 0 . 


\section{RASPRAVA I ZAKLJUČAK}

U ovom smo radu nastojali utvrditi strukturu ekonomskih stavova u Hrvatskoj te jesu li ti stavovi utemeljeni u socioekonomskom položaju pojedinca, odnosno, postoji li osnova za pojavu dimenzije političkog natjecanja koja se temelji na razlikama u stavovima o ekonomskim pitanjima. Varijable koje su se pokazale značajnima u obje regresijske analize, iako je njihov supstancijalni utjecaj zapravo vrlo slab, prije svega su varijable koje mjere izloženosti pojedinca i njegova kućanstva socijalnim i ekonomskim rizicima. Ekonomskom su protekcionizmu tako skloniji zaposleni u privatnom sektoru, koji su izloženiji pritiscima tržišta, od zaposlenih u javnom sektoru, i ispitanici s višom razinom izloženosti kreditu, odnosno dugu i hipotekama na imovinu. Na sličan se način može promatrati i učinak varijabli koje mjere broj djece i broj umirovljenika u kućanstvu, odnosno broj ekonomski neaktivnih članova. Veći broj ekonomski neaktivnih članova, koji zbog starosti ili školovanja ne mogu raditi, ograničava mogućnost povećanja prihoda na tržištu kroz zaposlenje dodatnih članova i čini kućanstvo ovisnijim o transferima i uslugama iz javnog sektora. Učinak varijable koja mjeri socijalnu isključenost odskače od opisanog obrasca, pri čemu izloženi višoj razini socijalne isključenosti nisu skloni protekcionističkim politikama. Slično odnosu prema ekonomskom protekcionizmu, ekonomski liberalizam ne podržavaju ispitanici koje karakterizira viša razina izloženosti različitim oblicima ekonomskih rizika, od nezaposlenosti, siromaštva i isključenosti te kredita. Može se stoga reći da su stavovi prema ekonomskom protekcionizmu zrcalna slika odnosa prema tržištu, pri čemu je ekonomski rizik glavni činitelj na kojem se temelje preferencije za protekcionističke politike i redistribuciju ekonomske moći.

Varijable koje mjere trajnije elemente socioekonomske pozicije, poput obrazovanja, zanimanja i imovinskog statusa, nisu se pokazale statistički, a ni supstancijalno, značajnim. Zanimanje kao jedna od glavnih determinanti socioekonomskog položaja nije pokazalo značajne efekte. Slično se može reći i za efekte obrazovanja i imovinskog statusa kao varijabli koje su se u komparativnim studijama pokazale kao konzistentno važnim determinantama stavova o ekonomskim pitanjima.

Ovaj rad potvrđuje, doduše u ograničenom kontekstu parlamentarnih izbora 2015. godine, da u Hrvatskoj ne postoji vidljiva povezanost između elemenata socioekonomske strukture, koji definiraju društvenu stratifikaciju poput zanimanja, obrazovanja ili imovinskog statusa s jedne te stavova o ulozi tržišta i države u ekonomiji s druge strane. Nepostojanje povezanosti ekonomskih stavova sa socioekonomskim statusom čini malo vjerojatnom pojavu političkih identiteta temeljenih na poziciji pojedinca u socioekonomskoj strukturi i ekonomskim interesima koji proizlaze iz nje te znatno manju mogućnost pojave ekonomskog rascjepa. 
Nadalje, činjenica da su sve varijable koje su se pokazale značajnima zapravo varijable koje mjere različite aspekte neposredne socijalne ugroženosti ili izloženosti ekonomskom riziku, a ne socioekonomski status, pokazuje da su stavovi o ekonomskim pitanjima zapravo prije svega reakcija na percepciju ugroženosti od ekonomskih rizika. Ipak, treba reći da su efekti i tih varijabli supstancijalno prilično slabi, da tek u zajedničkom učinku više varijabli vidimo znatniji utjecaj na stavove te da ih se ne može smatrati supstancijalno značajnim za objašnjenje stavova o ekonomskim pitanjima.

Međutim, treba reći i to da doseg nalaza regresijske analize u ovom radu ograničuje činjenica da je analiza povezanosti društvene strukture i stavova o ekonomskim pitanjima provedena na podacima prikupljenim u jednoj vremenskoj točki. Ograničenje analize na jednu vremensku točku onemogućuje donošenje zaključka izvan konteksta te vremenske točke i generalizaciju nalaza na dulje razdoblje, posebno u kontekstu nepostojanja drugih studija koje analiziraju taj fenomen na usporediv način i na drugim izvorima podataka.

Empirijska analiza u radu pokazala je postojanje dviju dimenzija stavova o ekonomskim pitanjima. Dok prva dimenzija izrazito nalikuje klasičnoj ekonomskoj dimenziji lijevo-desno, drugu dimenziju čini ekonomski protekcionizam, koji uključuje elemente zaštite domaće ekonomije od stranog kapitala, zaštite građana od banaka i korporacija i zaštite poduzetnika od državnog oporezivanja, i čiji sadržaj zapravo i nije neobičan za zemlju poput Hrvatske s teškom ekonomskom tranzicijom i relativno stagnantnom ekonomijom. S druge strane, taj nalaz može ukazivati na pojavu nove strukture stavova karakteristične za ekonomiju s velikim brojem građana, često samozaposlenih, povezanih s aktivnostima i prihodima manjeg opsega u sektoru usluga. Ti su građani osjetljivi na konkurenciju većih korporacija, visinu poreza i cijenu kredita, dok istodobno ne vide neposrednu korist od državne potrošnje i usluga javnog sektora. S obzirom na to da je fokus rada bio ograničen na analizu utjecaja socioekonomskog statusa, ovdje nismo uspjeli utvrditi na čemu se ta struktura stavova o ekonomskim pitanjima zapravo temelji niti smo uspjeli objasniti njezine izvore.

U konačnici, nalazi rada upućuju na to da u Hrvatskoj vrlo vjerojatno još ne postoje preduvjeti za pojavu socioekonomskog rascjepa koji će imati znatniji potencijal mobilizacije birača, čak ni u izborima održanima nakon duljeg razdoblja ekonomske krize. S druge strane, s obzirom na popularnost protekcionističkih stavova, može se reći da postoji prostor za mobilizaciju birača ekonomskim programom usmjerenim na zaštitu slabijih tržišnih aktera. Isto tako, pojava novih stranaka, koje po svemu sudeći podržavaju birači koji nemaju izraženu političku povezanost s identitetima ljevice i desnice, može otvoriti prostor za pojavu socioekonomskih rascjepa, pod uvjetom da determinante društvene pozicije postanu relevantnima 
za oblikovanje stavova o ulozi tržišta u ekonomiji i distribuciji dohotka. lako nove stranke podržavaju birači koji su nezadovoljni ekonomskim stanjem i izloženiji ekonomskom riziku, zasad nema naznaka da će na temelju te činjenice nastati trajniji rascjep koji će biti oblikovan pojavom političkih identiteta proizišlih iz ekonomskih interesa.

\section{LITERATURA}

Crusack T, Iversen T i Rehm P (2006). Risks at Work: The Demand and Supply Sides of Government Redistribution, Oxford Review of Economic Policy, 22 (3): 365-389. https:// doi.org/10.1093/oxrep/grj022

Čular G (2000). Political Development in Croatia 1990-2000: Fast Transition - Postponed Consolidation, Politička misao, 37 (5): 30-46.

Čular G i Zakošek N (2004). Croatia. U: Berglund S, Erman J, Deegan-Krause K i Knutsen T (ur.). The Handbook of Political Change in Europe. Cheltenham: Edward Elgar, 451-492.

DiPrete TA (2002). Life Course Risks, Mobility Regimes, and Mobility Consequences: A Comparison of Sweden, Germany, and the United States, American Journal of Sociology, 108 (2): 267-309. https://doi.org/10.1086/344811

Dolenec D (2012). The Absent Socioeconomic Cleavage in Croatia: A Failure of Representative Democracy?, Politička misao, 49 (5): 69-88.

Eichengreen B (2018). The Populist Temptation: Economic Grievance and Political Reaction in the Modern Era. Oxford: Oxford University Press.

Ferić I (2008). Sustav vrijednosti kao odrednica dominantnih političkih preferencija, Društvena istraživanja, 17 (4-5): 615-629.

Glaurdić J i Vuković V (2016). Voting after war: Legacy of conflict and the economy as determinants of electoral support in Croatia, Electoral studies, 42: 135-145. https://doi. org/10.1016/j.electstud.2016.02.012

Grdešić M (2013). Prostorna analiza 'crvene' i ‘crne' Hrvatske: eskplorativna studija, Politička misao, 50 (1): 183-203.

Henjak A (2007). Values or Interests: Economic Determinants of Voting Behaviour in the 2007 Croatian Parliamentary Elections, Politička misao, 44 (5): 71-90.

Henjak A (2011). Stranačka identifikacija i granice stranačke mobilizacije u Hrvatskoj nakon 2000. godine, Političke perspektive, 1 (1): 29-55.

Henjak A (2018). Nose li parlamentarni izbori 2015. i 2016. godine promjenu političkih rascjepa u Hrvatskoj?, Društvena istraživanja, 27 (3): 383-406. https://doi.org/10.5559/ di.27.3.01

Henjak A, Zakošek N i Čular G (2013). Croatia. U: Berglund S, Erman J, Deegan-Krause K i Knutsen T (ur.). Handbook of Political Change in Eastern Europe. Cheltenham: Edward Elgar, 443-480. https://doi.org/10.4337/9781782545880

Inglehart R i Norris P (2016). Trump, Brexit, and the Rise of Populism: Economic Have-Nots and Cultural Backlash, HKS Working Paper No. RWP16-026. https://doi.org/10.2139/ ssrn.2818659 
Iversen T i Rosenbluth F (2006). The Political Economy of Gender: Explaining Cross-National Variation in the Gender Division of Labor and the Gender Voting Gap, American Journal of Political Science, 50 (1): 1-19. https://doi.org/10.1111/j.1540-5907.2006.00166.x

Iversen T i Soskice D (2001). An Asset Theory of Social Policy Preferences, American Political Science Review, 95 (4): 875-893. https://doi.org/10.1017/S0003055400400079

Jou W (2010). Continuities and changes in left-right orientations in new democracies: The cases of Croatia and Slovenia, Communist and Post-Communist Studies, 43 (1): 97113. https://doi.org/10.1016/j.postcomstud.2010.01.007

Kitschelt H i Rehm P (2014). Occupations as a Site of Political Preference Formation, Comparative Political Studies, 47 (12): 1670-1706. https://doi. org/10.1177/0010414013516066

Knutsen O (2002). Social Class, Sector Employment, and Gender as Party Cleavages in the Scandinavian Countries: A Comparative Longitudinal Study, 1970-95, Scandinavian Political Studies, 24 (4): 311-350. https://doi.org/10.1111/1467-9477.00058

Macy M (1988). New-class dissent among social-cultural specialists: The effects of occupational self-direction and location in the public sector, Sociological Forum, 3 (3): 325-356.

Marx P (2014). The Effect of Job Insecurity and Employability on Preferences for Redistribution in Western Europe, Journal of European Social Policy, 24 (4): 351-366. https://doi.org/10.1177/0958928714538217

Mayda AM i Rodrik D (2005). Why are some people (and countries) more protectionist than others?, European Economic Review 49 (6): 1393-1430. https://doi.org/10.1016/j. euroecorev.2004.01.002

McCall L i Kenworthy L (2009). Americans' Social Policy Preferences in the Era of Rising Inequality, Perspectives on Politics, 7 (3): 459-484. https://doi.org/10.1017/ S1537592709990818

Oesch D (2006). Redrawing the Class Map: Stratification and Institutions in Britain, Germany, Sweden and Switzerland. Basingstoke: Palgrave Macmillan.

Oesch D (2013). Occupational Change in Europe: How Technology and Education Transform the Job Structure. Oxford: Oxford University Press.

Rehm P (2009). Risks and Redistribution: An Individual-Level Analysis, Comparative Political Studies, 42 (7): 855-881. https://doi.org/10.1177/0010414008330595

Rimac I, Burić I i Štulhofer A (2017). Višerazinsko modeliranje egalitarnog sindroma i validacija kratke skale SEMA-5, Politička misao, 54 (3): 64-79.

Schwander Hi Häusermann S (2013). Who is in and who is out? Arisk-based conceptualization of insiders and outsiders, Journal of European Social Policy, 23 (3): 248-269. https://doi. org/10.1177/0958928713480064

Stubager R (2008). Education effects on authoritarian-libertarian values: A question of socialization, The British Journal of Sociology, 59: 327-350. https://doi.org/10.1111/ j.1468-4446.2008.00196.x

Šiber I (1997). Izborne orijentacije i ideologijski sukobi tijekom Drugoga svjetskog rata: Značenje političke biografije obitelji, Politička misao, 34 (2): 104-128.

Šiber I (2001). Političko ponašanje birača u izborima 1990-2000. U: Kasapović M (ur.). Hrvatska politika 1990.-2000.: Izbori, stranke i parlament u Hrvatskoj. Zagreb: Fakultet političkih znanosti, 65-99. 
Štulhofer A i Burić I (2015). Je li egalitarni sindrom samo teorijska fantazija? Empirijski hommage Josipu Županovu, Politička misao, 52 (3): 7-31.

Van de Werfhorst H i De Graaf ND (2004). The sources of political orientations in postindustrial society: Social class and education revisited, The British Journal of Sociology, 55: 211-235. https://doi.org/10.1111/j.1468-4446.2004.00016.x

Vuković V, Štulhofer A i Burić I (2017). Je li Županov imao pravo? Testiranje podrijetla i perzistencije egalitarnoga sindroma, Društvena istraživanja, 26 (2): 207-225. https://doi. org/10.5559/di.26.2.04

Weakliem DL (2002). The Effects of Education on Political Opinions: An International Study, International Journal of Public Opinion Research, 14 (2): 141-157. https://doi. org/10.1093/ijpor/14.2.141

Weeden KA i Grusky DB (2005). The Case for a New Class Map, American Journal of Sociology, 111 (1): 141-212. https://doi.org/10.1086/428815

Wren A i Rehm P (2013). Service Expansion, International Exposure, and Political Preferences. U: Wren A (ur.). The Political Economy of the Service Transition. Oxford: Oxford University Press, 248-281.

Zakošek N (1994). Struktura i dinamika hrvatskoga stranačkog sustava, Revija za sociologiju, 25 (1-2): 23-39.

Zakošek N (1998). Ideološki rascjepi i stranačke preferencije hrvatskih birača. U: Kasapović M, Šiber I i Zakošek N (ur.). Birači i demokracija: utjecaj ideoloških rascjepa na politički život. Zagreb: Alinea, 11-50.

Zakošek N, (2001). Struktura biračkog tijela i političke promjene u siječanjskim izborima 2000., u: Mirjana Kasapović (ur.). Hrvatska politika 1990-2000: izbori, stranke i parlament u Hrvatskoj. Zagreb: Fakultet političkih znanosti, 99-122. 


\title{
Interests or Something Else? Economic Attitudes in Croatia and their Foundation in Social Structure
}

\author{
Andrija HENJAK \\ Faculty of Political Science, University of Zagreb, Croatia \\ ahenjak@fpzg.hr

\section{Bartul VUKSAN ĆUSA} \\ Faculty of Political Science, University of Zagreb, Croatia \\ bvuksan@fpzg.hr
}

\section{ABSTRACT}

Existing empirical research has demonstrated that Croatian politics is dominated by political cleavages based on attitudes toward history and sociocultural values and by the absence of divisions between voters based on economic and distributive issues. However, the absence of political competition based on redistributive issues does not mean that a structure of attitudes related to economic issues does not exist and that these attitudes are not grounded in individuals' positions within the social structure. Using survey data collected following the parliamentary elections of 2011, 2015 and 2016 on representative probabilistic national samples of 1,000 participants, the authors explored the structure of attitudes toward distributive issues in Croatia. Using the regression analysis and data collected in $\mathbf{2 0 1 5}$ on a representative probabilistic national sample of 1,260 respondents in the second step, the authors examined the associations between economic attitudes and socioeconomic position. The analyses indicated a clear and relatively stable structure of attitudes towards economic issues consisting of two dimensions, one encompassing economic protectionism and the other views about the role of markets as an economic organising principle. However, a very weak association between elements of the social structure and attitudes towards distributive issues was found.

Key words: socioeconomic structure, economic protectionism, economic liberalism, economic attitudes, political cleavages 